\title{
USE OF WASTEWATER IN THE PRODUCTION OF AROEIRA SEEDLINGS ${ }^{1}$
}

\author{
RAIMUNDO FERNANDES DE BRITO ${ }^{2}$, MIGUEL FERREIRA NETO ${ }^{3}$, MARIA ALCILENE MORAIS ${ }^{3}$, NILDO DA \\ SILVA DIAS $^{3 *}$, RANIERE BARBOSA DE LIRA ${ }^{4}$
}

\begin{abstract}
The use of wastewater has emerged as alternative to control environmental pollution and a viable option to improved water availability in the arid and semiarid zones. In this study, the effects of irrigation solution with domestic sewage effluent and, of growing substrate on growth of Aroeira seedlings was examined in a greenhouse experiment. The effects of five irrigation solution (Public-supply water, PSW, domestic sewage effluent, DSE and the mixtures of 75\% DSE + 25\% PSW, 50\% DSE + 50\% PSW and 25\% DSE $+75 \%$ PSW) and two growing substrate $(75 \%$ soil $+25 \%$ bovine manure and, $75 \%$ soil $+25 \%$ coconut fiber) were used in a completely randomized block design, arranged as split plots with three replications for each treatment. The evaluations were made at 30,60, 90 and 150 days after planting, and the parameters following were measured: stem diameter, shoot height, relationship between height and diameter, shoot/root dry matter ratio, dry matter of the root, shoot and total and, Dickson index. The analysis results indicated that the irrigation solution composed by raw sewage effluent or mixed with Public-supply water increased the growth and improved morphological index of Aroeira seedlings, being the better development found when plant of Aroeira were grown in bovine manure + soil substrate under irrigation with solution containing $100 \%$ domestic sewage effluent.
\end{abstract}

Keywords: Water reuse. Myracrodruon Urundeuva L.. Caatinga species.

\section{USO DE ÁGUA RESIDUÁRIAS NA PRODUÇÃo DE MUDAS DE A AROEIRA}

RESUMO - O uso das águas residuais tem despontado como uma alternativa para o controle da poluição ambiental e uma opção viável para aumentar a disponibilidade hídrica nas regiões áridas e semiáridas. Neste estudo, os efeitos da água de irrigação com efluente de esgoto doméstico e do substrato de cultivo sob o crescimento de mudas de Aroeira foram estudados em um experimento em condições de ambiente protegido. Foram testados cinco soluções de irrigação (Água de abastecimento - AA, Efluente de esgoto doméstico bruto ED e as misturas de $75 \%$ ED $+25 \%$ AA, $50 \%$ ED $+50 \%$ AA e $25 \%$ ED $+75 \%$ AA) e dois substratos de cultivos $(75 \%$ solo $+25 \%$ esterco de bovinos e $75 \%$ solo $+25 \%$ fibra de coco) utilizando o delineamento estatístico inteiramente casualizado, arranjadas em parcelas subdivididas com três repetições com três repetições por tratamento. As avaliações de crescimento e desenvolvimento foram realizadas aos 30; 60; 90 e 150 dias após o plantio e determinaram-se as variáveis diâmetro do colo, altura de parte aérea, relação entre altura e o diâmetro, relação matéria seca da parte aérea/matéria seca da raiz, matérias secas do sistema radicular, da parte aérea, total, e o índice de Dickson. As análises dos resultados indicaram que a irrigação com efluente de esgoto aumentou o crescimento e o índice morfológico das mudas de aroeira, sendo o melhor desenvolvimento encontrado quando as plântulas de Aroeira foram cultivadas em substrato de esterco bovino + solo e irrigadas com solução contendo $100 \%$ efluente de esgoto doméstico tratado.

Palavras-chave: Água de reuso. Myracrodruon Urundeuva L.. Espécie da caatinga.

\footnotetext{
${ }^{*}$ Corresponding author

${ }^{1}$ Received for publication in 12/02/2016; accepted in 07/05/2017.

Paper extracted from the doctoral thesis of the first author.

${ }^{2}$ Empresa de Assistência Técnica e Extensão Rural, Assú, RN, Brazil; haranha1@hotmail.com - ORCID: 0000-0003-3619-6108.

${ }^{3}$ Center of Agrarian Sciences, Universidade Federal Rural do Semi-Árido, Mossoró, RN, Brazil; miguel@ufersa.edu.br - ORCID: 00000002-5128-8230, alcilenemorais@gmail.com - ORCID: 0000-0001-5632-0546, nildo@ufersa.edu.br-ORCID: 0000-0002-1276-5444.

${ }^{4}$ Cooperativa de Assessoria e Serviços Múltiplos ao Desenvolvimento Rural, Mossoró, RN, Brazil; ranierejunco@gmail.com - ORCID: 0000-0003-4439-4649.
} 


\section{INTRODUCTION}

Water scarcity has become one of the greatest challenges facing the world, because of the crisis in its supply, which particularly affects semi-arid regions and is a determinant factor for social and economic development.

The use of domestic sewage effluent in irrigated agriculture has been recommended by many authors as an alternative to controlling environmental pollution, as a feasible option to increase water availability in arid and semi-arid regions (SOUZA et al., 2010; ASGHARIPOUR; AZIZMOGHADDAM, 2012; SARAIVA; KONIG, 2013).

In the context of the large-scale reuse of domestic sewage effluent, forestry activity, due to its particularities, presents itself as a promising alternative, especially since it does not involve the production of food for human consumption. The stimulus for the production of seedlings of native forest species aimed at the recovery of degraded areas is one way of not only replenishing and maintaining forest resources, but also preserving economic, social and environmental balance.

For these reasons, water reuse has great potential to play a very important role in the production of native seedlings, to minimize production costs.

Aroeira-do-sertão (Myracrodruon urundeuva L.) was selected for seedling production because it plays important roles in semi-arid regions, such as utilization of wood in rural properties, extraction of tannins, as well as in pharmacology and beekeeping (CARLINI et al., 2010).

On the other hand, besides the alternative in terms of water for production, it is important to have a growing substrate available that guarantees good initial development of the seedlings at low cost, because the substrate is used to support plants during the rooting stage and serves as a source of nutrients, exerting a significant influence on seedling development.

Considering these aspects, this study aimed to investigate the effects of irrigation solutions with treated domestic sewage effluent and growing substrates on the growth and development of aroeira seedlings.

\section{MATERIAL AND METHODS}

The study was carried out in a greenhouse of the Department of Environmental and Technological Sciences of the Federal Rural University of the Semi-Arid Region (UFERSA), in Mossoró city - RN $\left(5^{\circ} 11^{\prime} \mathrm{S}, 37^{\circ} 20^{\prime} \mathrm{W} ; 18 \mathrm{~m}\right)$, from January to June 2015 .

Five irrigation solutions (Public-supply water, PSW, domestic sewage effluent, DSE and the mixtures of $75 \%$ DSE + 25\% PSW, $50 \%$ DSE $+50 \%$ PSW and $25 \%$ DSE $+75 \%$ PSW) and two growing substrates $\left(75 \%\right.$ soil $+25 \%$ bovine manure $-\mathrm{S}_{1}$ and $75 \%$ soil $+25 \%$ coconut fiber $-\mathrm{S}_{2}$ ) were tested using a completely randomized design, arranged in split plots with three replicates per treatment.

Aroeira-do-sertão (Myracrodruon urundeuva L.) seeds were collected in the period from July to August 2014 from vigorous trees with spontaneous occurrence in a radius of 50 metres in the municipality of Apodi-RN, when they were fully mature (firm texture, rough aspect and dark brown color), the moment when the seeds reached physiological maturity, exhibiting maximum germination power and vigor (HOPPE; BRUN, 2004).

Since it is a tall species, seeds were collected directly from the crown using pruning scissors attached to the tip of a rod, by cutting the seed-bearing branches. After collection, the seeds were taken to the UFERSA, cleaned, placed in paper bags $(20 \times 10 \mathrm{~cm})$ and stored in hermetically sealed glass containers in a cool place at room temperature.

After preparing the growing substrates used in the experiment, samples were collected for physical-chemical analysis at the Soil Fertility Laboratory (LASAP) of the UFERSA (Table 1).

Table 1. Physical-chemical attributes of the growing substrates used in the experiment.

\begin{tabular}{|c|c|c|c|c|c|c|c|c|c|c|c|c|c|c|c|c|c|}
\hline Substrates* & $\mathrm{pH}$ & $\begin{array}{l}\mathrm{OM} \\
\mathrm{g} \mathrm{kg}^{-1}\end{array}$ & $\begin{array}{l}\mathrm{EC}^{\mathrm{W}} \\
\mathrm{dS} \mathrm{m}^{-1}\end{array}$ & $\mathrm{C} / \mathrm{N}$ & \multicolumn{10}{|c|}{$\mathrm{mg} \mathrm{dm}^{-3}$} & \multicolumn{2}{|c|}{$\mathrm{cmol}_{\mathrm{c}} \mathrm{dm}^{-3}$} & $\begin{array}{l}\mathrm{m} \\
\%\end{array}$ \\
\hline W & 6.4 & 12.4 & 1.6 & $24: 1$ & 39 & 240 & 125 & 28.3 & 0.1 & 0.7 & 3.1 & 2.1 & 0.6 & 0.0 & 3.1 & 4.0 & $\overline{0.0}$ \\
\hline $\mathrm{S}_{2}$ & 5.6 & 10.5 & 1.7 & $73: 1$ & 36 & 181 & 120 & 23.1 & 0.3 & 0.9 & 0.5 & 1.8 & 0.6 & 0.0 & 2.7 & 3.2 & 0.0 \\
\hline
\end{tabular}

$* \mathrm{~S}_{1}=75 \%$ soil $+25 \%$ bovine manure $\mathrm{S}_{2}=75 \%$ soil $+25 \%$ coconut fiber.

The public-supply water used in the experiment to irrigate aroeira seedlings came from the hydraulic network of the UFERSA campus. The domestic sewage effluent came from the Domestic Sewage Treatment Station of the Milagre do Apodi Settlement Project (RN), composed of 20 households and approximately 90 people, producing a daily volume of $20 \mathrm{~m}^{3}$ of domestic wastewater.

To estimate the amount of nutrients supplied to the plants through the volumes of domestic sewage effluent (DSE) and public-supply water (PSW), samples were collected for physical-chemical analysis (Table 2). 
Table 2. Physical-chemical analysis of the domestic sewage effluent and Supply water used in the experiment.

\begin{tabular}{|c|c|c|c|}
\hline Sewege efluente & Value & Supply water & Value \\
\hline $\mathrm{EC}\left(\mathrm{dS} \mathrm{m^{-1 } )}\right.$ & 1.2 & $\mathrm{EC}\left(\mathrm{dS} \mathrm{m}^{-1}\right)$ & 0.52 \\
\hline $\mathrm{pH}$ & 7.3 & $\mathrm{pH}$ & 7.4 \\
\hline $\mathrm{SS}\left(\mathrm{mg} \mathrm{L}^{-1}\right)$ & 44 & $\mathrm{SS}\left(\mathrm{mg} \mathrm{L}^{-1}\right)$ & 0.0 \\
\hline $\mathrm{DS}\left(\mathrm{mg} \mathrm{L}^{-1}\right)$ & 350 & $\mathrm{DS}\left(\mathrm{mg} \mathrm{L}^{-1}\right)$ & 50 \\
\hline $\mathrm{Fe}\left(\mathrm{mg} \mathrm{L}^{-1}\right)$ & 0.60 & $\mathrm{Fe}\left(\mathrm{mg} \mathrm{L}^{-1}\right)$ & 1.4 \\
\hline $\operatorname{Mn}\left(\mathrm{mg} \mathrm{L}^{-1}\right)$ & 0.20 & $\operatorname{Mn}\left(\mathrm{mgL}^{-1}\right)$ & 1.1 \\
\hline $\mathrm{Ca}^{2+}\left(\mathrm{mgL}^{-1}\right)$ & 32.06 & $\mathrm{Ca}^{2+}\left(\mathrm{mg} \mathrm{L}^{-1}\right)$ & 12.02 \\
\hline $\mathrm{Mg}^{2+}\left(\mathrm{mg} \mathrm{L}^{-1}\right)$ & 17.01 & $\mathrm{Mg}^{2+}\left(\mathrm{mg} \mathrm{L}^{-1}\right)$ & 12.15 \\
\hline $\mathrm{Cu}\left(\mathrm{mg} \mathrm{L}^{-1}\right)$ & 0.06 & $\mathrm{Cu}\left(\mathrm{mg} \mathrm{L}^{-1}\right)$ & \\
\hline $\mathrm{Zn}\left(\mathrm{mg} \mathrm{L}^{-1}\right)$ & 0.09 & $\mathrm{Zn}\left(\mathrm{mg} \mathrm{L}^{-1}\right)$ & \\
\hline $\mathrm{COD}\left(\mathrm{mg} \mathrm{L}^{-1}\right)$ & 60.00 & $\mathrm{Fe}\left(\mathrm{mg} \mathrm{L}^{-1}\right)$ & - \\
\hline $\mathrm{BOD}\left(\mathrm{mg} \mathrm{L}^{-1}\right)$ & 19.40 & $\mathrm{Fe}\left(\mathrm{mg} \mathrm{L}^{-1}\right)$ & - \\
\hline N Total $\left(\mathrm{mg} \mathrm{L}^{-1}\right)$ & 72.00 & $\mathrm{~N}$ Total $\left(\mathrm{mg} \mathrm{L}^{-1}\right)$ & 0.0 \\
\hline P Total $\left(\mathrm{mg} \mathrm{L}^{-1}\right)$ & 7.5 & P Total $\left(\mathrm{mg} \mathrm{L}^{-1}\right)$ & - \\
\hline $\mathrm{K}^{+}\left(\mathrm{mg} \mathrm{L}^{-1}\right)$ & 47.7 & $\mathrm{~K}^{+}\left(\mathrm{mg} \mathrm{L}^{-1}\right)$ & 11.5 \\
\hline $\mathrm{Na}^{+}\left(\mathrm{mg} \mathrm{L}^{-1}\right)$ & 161.61 & $\mathrm{Na}^{+}\left(\mathrm{mg} \mathrm{L}^{-1}\right)$ & 10.57 \\
\hline $\mathrm{N}^{-\mathrm{No}_{3}}{ }^{-}\left(\mathrm{mg} \mathrm{L}^{-1}\right)$ & 0.10 & $\mathrm{~N}-\mathrm{No}_{-3}\left(\mathrm{mg} \mathrm{L}^{-1}\right)$ & 0.0 \\
\hline $\mathrm{TC}\left(\right.$ mmolc L $\left.^{-1}\right)$ & 2.40 & $\mathrm{CT}\left(\right.$ mmolc L $\left.{ }^{-1}\right)$ & \\
\hline $\begin{array}{l}\text { Termotolerant Coliform (MPN } \\
100 \mathrm{~mL}^{-1} \text { ) }\end{array}$ & $8 \times 10^{4}$ & $\begin{array}{l}\text { Termotolerant Coliform } \\
\left(\text { MPN } 100 \mathrm{~mL}^{-1} \text { ) }\right.\end{array}$ & 0.0 \\
\hline
\end{tabular}

Seedlings were manually irrigated twice a day, using a graduated cup to measure the volume of water applied, which was sufficient to maintain maximum water capacity in the substrate. Maximum water capacity in the substrate inside the growing container was determined twice a week through tensiometry and water retention curve for each treatment. Irrigation was performed by gradually adding water to the substrate and collecting the drained water.

Aroeira-do-sertão seedlings were evaluated for growth and development at 30,60, 90 and 150 days after planting (DAP), based on the following variables: a) Plant height - obtained as the distance between substrate surface and insertion of the last pair of leaves, using a ruler $(\mathrm{cm})$; b) Collar diameter - measured with a digital caliper in the stem region at height of $2 \mathrm{~cm}$ from substrate surface $(\mathrm{mm})$; c) Longest root length - measured from the base of the plant to the tip of the root, using a ruler $(\mathrm{mm})$; d) Number of leaves - obtained by counting the leaves in each plant; e) Plant fresh matter - determined by individually weighing the roots, stems and leaves of the plants $\left(\mathrm{g} \mathrm{plant}^{-1}\right)$; Plant dry matter - determined by individually weighing the roots, stems and leaves of the plants, which were subsequently dried in an oven at $70{ }^{\circ} \mathrm{C}\left(\mathrm{g}_{\text {plant }}{ }^{-1}\right)$.

In addition, the following ratios were calculated: plant height/collar diameter, plant height/ shoot dry matter, shoot dry matter/root dry matter, as well as Dickson quality index.

At the end of the experiment, leaf samples from the plants in each treatment were ground in Wiley-type mill for chemical analyses (nitrogen, phosphorus, potassium, calcium and magnesium) according to the methodology suggested by Tedesco et al. (1995).

The data were subjected to analysis of variance by $F$ test and to Tukey test, both at 0.05 probability level, using the statistical program SISVAR $®$ (FERREIRA, 2011).

\section{RESULTS AND DISCUSSION}

According to the ANOVA, the sewage effluent dilutions have an effect on the variables plant height $(\mathrm{PH})$, collar diameter (CD), Dickson quality index (DQI), root dry matter (RDM), number of leaves $(\mathrm{NL})$ and shoot/root ratio $(\mathrm{S} / \mathrm{R})$ of aroeira plants, as a function of the waste water (Table 3 ). 
Table 3. Analysis of variance and mean values of plant height (PH), collar diameter (CD), Dickson quality index (DQI), root dry matter $(\mathrm{RDM})$, total dry matter (TDM), number of leaves $(\mathrm{NL})$ and shoot/root ratio (S/R) of aroeira plants irrigated with sewage effluent in different growing substrates ${ }^{1}$.

\begin{tabular}{lccccccc}
\hline \multicolumn{1}{c}{ Irrigation solutions } & $\begin{array}{c}\mathrm{PH} \\
(\mathrm{cm})\end{array}$ & $\begin{array}{c}\mathrm{CD} \\
(\mathrm{mm})\end{array}$ & DQI & $\begin{array}{c}\text { RDM } \\
\left(\mathrm{g} \mathrm{kg}^{-1}\right)\end{array}$ & $\begin{array}{c}\mathrm{TDM} \\
\left(\mathrm{g} \mathrm{kg}^{-1}\right)\end{array}$ & $\mathrm{NL}$ & $\mathrm{S} / \mathrm{R}$ \\
\hline PSW & $32.81 \mathrm{~B}$ & $3.55 \mathrm{~B}$ & $0.54 \mathrm{~B}$ & $2.20 \mathrm{~B}$ & $5.94 \mathrm{~B}$ & $16.05 \mathrm{~B}$ & $2.65 \mathrm{~A}$ \\
$25 \% \mathrm{DSE}+75 \% \mathrm{PSW}$ & $32.46 \mathrm{~B}$ & $3.44 \mathrm{~B}$ & $0.50 \mathrm{~B}$ & $2.11 \mathrm{~B}$ & $5.57 \mathrm{~B}$ & $14.65 \mathrm{~B}$ & $2.04 \mathrm{~A}$ \\
$50 \% \mathrm{DSE}+50 \% \mathrm{PSW}$ & $31.47 \mathrm{~B}$ & $3.29 \mathrm{~B}$ & $0.44 \mathrm{~B}$ & $1.77 \mathrm{~B}$ & $4.53 \mathrm{~B}$ & $14.70 \mathrm{~B}$ & $2.01 \mathrm{~A}$ \\
$75 \% \mathrm{DSE}+25 \% \mathrm{PSW}$ & $31.91 \mathrm{~B}$ & $3.56 \mathrm{~B}$ & $0.43 \mathrm{~B}$ & $1.73 \mathrm{~B}$ & $4.70 \mathrm{~B}$ & $15.40 \mathrm{~B}$ & $2.23 \mathrm{~A}$ \\
$100 \% \mathrm{DSE}$ & $41.97 \mathrm{~A}$ & $5.28 \mathrm{~A}$ & $1.45 \mathrm{~A}$ & $5.55 \mathrm{~A}$ & $9.14 \mathrm{~A}$ & $24.15 \mathrm{~A}$ & $1.71 \mathrm{~A}$ \\
\hline
\end{tabular}

${ }^{1}$ Means followed by the same capital letter in lowercase in the column do not differ between each other at $5 \%$ probability by the Tukey test.

The development in height and diameter of aroeira seedlings was significantly superior in the $100 \%$ DSE treatment (Table 3) at 150 DAP, probably due to the higher concentration of micronutrients in the irrigation solution with only the effluent. In addition, at the end of the experiment, the seedlings showed heights greater than those suggested for planting $(>30 \mathrm{~cm})$, due to the high growth rate in the last 30 days of the cycle under $100 \%$ DSE application.

The data obtained by Santos et al. (2007) confirm these results. These authors produced seedlings native to the Caatinga using treated domestic sewage and observed that Ipê roxo seedlings irrigated with domestic sewage effluent showed a slightly inferior initial growth compared with those irrigated with public-supply water and, only from 30 DAP on, their development became superior and increasing, similar to the Aroeira seedlings in the present experiment.

That study also found that Angicos seedlings irrigated with public-supply water showed greater development in height and collar diameter, which the researcher attributed to the high $\mathrm{pH}$ level and, particularly, to the high electrical conductivity of the sewage effluent.

Regarding the plant height and collar diameter variables, Gomes et al. (2002) point out that these characteristics are important indicators, because seedlings with higher values of height and collar diameter have a greater possibility to show balanced shoot growth. These authors recommend a minimum collar diameter of $3.5 \mathrm{~mm}$ for planting the seedlings in the field. Thus, it can be inferred that the mean values of diameter found in the present study were adequate, including those of seedlings irrigated with $25 \%$ DSE $+75 \%$ PSW solution (3.55- $3.56 \mathrm{~mm})$. On the other hand, seedlings irrigated only with $100 \%$ DSE showed a much higher value of collar diameter in comparison to the other treatments $(5.28 \mathrm{~mm})$ (Table 3$)$.

Other authors have presented different reference values. For example, Gomes et al. (2002) established a minimum collar diameter of $2 \mathrm{~mm}$, and Lopes et al. (2007) recommended value of $2.5 \mathrm{~mm}$ for planting Eucalyptus grandis in the field. It is worth pointing out that, for the parameter collar diameter, all seedlings in the present study, regardless of treatment, are suitable to be transplanted to the field. However, one should not consider a single parameter in evaluating seedling quality.

Defining a collar diameter value that accurately represents the actual quality standard of the seedlings for planting in a definitive site depends on species, site, method and techniques of production, and many researchers recommend values higher than $6.4 \mathrm{~mm}$.

According to Table 3, irrigations using solutions with higher proportion of treated domestic sewage improved root system development, which became more vigorous and without twisting. Seedlings irrigated with public-supply water and with 25,50 and $75 \%$ sewage effluent did not differ statistically, whereas the $100 \%$ DSE treatment was superior to the others, leading to mean root dry matter of $5.5 \mathrm{~g} \mathrm{~kg}^{-1}$ (Table 3).

Root dry matter has been known as an important parameter in estimating seedling survival and growth rates in the field, i.e., the more abundant the root system, the greater the chances of success in the field, regardless of shoot height (GOMES et al., 2002). The significant effect on plants in the $100 \%$ DSE treatment, for both shoots and roots, was possibly due to the higher concentration of macronutrients available in the sewage effluent.

Oliveira et al. (2012) evaluated the growth of Sabiá and Mororó seedlings fertigated with treated domestic sewage effluent and observed that the root dry matter and total dry matter of Mororó showed better results when plants were irrigated with a solution of $50 \%$ effluent diluted in public-supply water.

The shoot/root ratio of aroeira seedlings was also supported by the application of $100 \%$ DSE irrigation solution, which can represent a desirable characteristic for greater mechanical balance of the seedlings under field conditions (Table 3). The results relating to irrigation solution treatments did not differ, although greater root development was observed in plants irrigated with $100 \%$ DSE. 
In general, plants showed balance between shoots and roots, indicating good survival at the field, not only due to better physical balance (responsible for seedling support), but also to higher water absorption capacity and better balance between transpiration and absorption. The ratio between shoot dry matter and root dry matter of the seedlings is considered an efficient and safe index to express the quality standard relative to balance, and its best value is 2.0 .

For the Dickson quality index, the treatment with $100 \%$ DSE solution was superior to the others (1.45), while the treatments with irrigation solution using public-supply water and 25,50 and $75 \%$ DSE did not differ statistically (mean values of $0.54,0.5$, 0.44 and 0.43 , respectively) (Table 3 ).

Gomes et al. (2002) established DQI of 0.20 as good indicator for seedlings of Pseudotsuga menziesii and Picea abies. These authors consider that this value is also recommended for Eucalyptus grandis seedlings produced in the largest tubes $(200$ and $280 \mathrm{~cm}^{3}$ ) and with 120 days after planting. Taking this reference value as a parameter for aroeira seedlings, plants exhibited balance, regardless of the treatments.

There was significant difference of the factor irrigation solution for the variable total dry matter, and the highest mean value occurred in aroeira seedlings irrigated with $100 \%$ DSE solution (9.14 $\mathrm{g} \mathrm{Kg}^{-1}$ ), while the other treatments did not differ (Table 3).

Table 4 shows the follow-up analysis of the interaction between types of irrigation solution and types of substrate for shoot dry matter and plant height/collar diameter ratio. Shoot/root ratio was not significant and the interaction between irrigation solution vs growing substrate had effect only on shoot dry matter and plant height/collar diameter ratio.

Table 4. Follow-up analysis of the interaction between the factors irrigation solution and growing substrates for shoot dry matter and plant height/collar diameter ratio of aroeira plants ${ }^{1}$.

\begin{tabular}{|c|c|c|c|c|c|c|}
\hline \multirow{3}{*}{ Irrigation solutions } & \multicolumn{3}{|c|}{ shoot dry matter } & \multicolumn{3}{|c|}{ plant height/collar diameter ratio } \\
\hline & \multicolumn{2}{|c|}{ Substrates } & \multirow{2}{*}{ Means } & \multicolumn{2}{|c|}{ Substrates } & \multirow{2}{*}{ Mean } \\
\hline & $\mathrm{S}_{1}$ & $\mathrm{~S}_{2}$ & & $\mathrm{~S}_{1}$ & $\mathrm{~S}_{2}$ & \\
\hline PSW & $2.71 \mathrm{Ba}$ & 4.76 Aba & 3.74 & $11.11 \mathrm{Aa}$ & $8.27 \mathrm{Aa}$ & 9.69 \\
\hline $25 \% \mathrm{DSE}+75 \% \mathrm{PSW}$ & $2.70 \mathrm{Ba}$ & 4.3 Aba & 3.47 & $9.15 \mathrm{Aba}$ & $10.19 \mathrm{Aa}$ & 9.67 \\
\hline $50 \%$ DSE + 50\%PSW & $3.19 \mathrm{Ba}$ & $2.33 \mathrm{Ba}$ & 2.76 & $9.07 \mathrm{Aba}$ & $10.08 \mathrm{Aa}$ & 9.58 \\
\hline $75 \% \mathrm{DSE}+25 \% \mathrm{PSW}$ & $2.65 \mathrm{Ba}$ & $3.27 \mathrm{Ba}$ & 2.96 & $8.81 \mathrm{Aba}$ & $9.55 \mathrm{Aa}$ & 9.18 \\
\hline $100 \% \mathrm{DSE}$ & $9.85 \mathrm{Aa}$ & $7.32 \mathrm{Ab}$ & 8.59 & $7.66 \mathrm{Ba}$ & $8.11 \mathrm{Aa}$ & 7.89 \\
\hline Means & 4.22 & 4.38 & - & 9.16 & 9.24 & - \\
\hline \multicolumn{3}{|c|}{ CV $(\%):$ plots $=49.13 ;$ subplots $=24.97$} & & ots $=20.89$ & ts $=22.85$ & \\
\hline
\end{tabular}

${ }^{1}$ Means followed by the same capital letter in line or lowercase in the column do not differ between each other at $5 \%$ probability by the Tukey test. $\mathrm{S}_{1}=75 \%$ soil $+25 \%$ bovine manure $\mathrm{S}_{2}=75 \%$ soil $+25 \%$ coconut fiber.

Irrigation with $100 \%$ DSE solution led to higher mean value of shoot dry matter, compared with the others, but did not differ when seedlings were grown in the substrate Soil + Bovine manure. However, when aroeira seedlings were grown in Soil + Coconut fiber, irrigation with $100 \%$ DSE solution was superior to the others and to solutions containing sewage effluent and only public-supply water. Irrigation solutions with $100 \%$ PSW and $75 \%$ $\mathrm{PSW}+25 \%$ DSE caused an intermediate behavior in this characteristic, which can be attributed to the higher contents of $\mathrm{N}, \mathrm{P}$ and $\mathrm{K}$ present in the sewage effluent, 100\% DSE (Table 4).

Irrigation solutions did not differ with respect to shoot dry matter compared in each substrate, except for the $100 \%$ DSE solution, for which the substrate Soil + Bovine manure was superior to Soil + Coconut fiber. The substrate Soil + Bovine manure has a lower carbon/nitrogen $(\mathrm{C} / \mathrm{N})$ ratio compared with Soil + Coconut fiber, thus supplying a greater amount of nutrients to the plant, which allows greater increment of biomass in the treatments containing bovine manure, besides the higher contents of $\mathrm{N}$ and $\mathrm{P}$ in its composition. Confirming the results found in the present study, Augusto et al. (2003) worked with production of Capixingui and Copaiba seedlings and concluded that sewage effluent favored increments in their dry matter production.

Aroeira seedlings showed a better response in the substrate containing bovine manure, due to the longer release of its nutrients to the root system. Each plant species has a preference for a certain combination of substrate. Probably, the studied species expressed such a preference through the variable shoot dry matter.

For the plant height/collar diameter ratio of the seedlings grown in Soil + Bovine manure, the $100 \%$ PSW solution was superior to the others and the $100 \%$ DSE solution led to the lowest mean values. The other irrigation solutions caused intermediate responses. For the substrate 
Soil + Coconut fiber, the solutions did not differ (Table 4).

Since the substrate with coconut fiber is not biologically stable, i.e., well composted, its $\mathrm{C} / \mathrm{N}$ ratio is high and can cause competition between microorganisms and seedlings for nutrients. Gomes and Paiva (2006) claim that plant height, associated with collar diameter, is one of the most important morphological characteristics for estimating seedling growth. There were no increments in plant height, probably because of the reduced amount of organic matter present in the substrate Soil + Coconut fiber.
According to Table 5, the mean values of growth in height did not show significant difference for the factor irrigation solution between the initial growth stages (30,60 and 90 days after planting), whereas in the final growth stages (120 and 150 days after planting), the treatment with sewage effluent (100\% DSE) was superior to the others. At 120 days, the solution with $25 \%$ DSE $+75 \%$ PSW led to the lowest mean values of plant height. At 150 days, the solutions of $100 \%$ PSW, $25 \%$ DSE $+75 \%$ PSW, $50 \%$ DSE $+50 \%$ PSW and $75 \%$ DSE $+25 \%$ DSE did not differ.

Table 5. Mean values of plant height (PH), collar diameter (CD) and total dry matter (TDM) of aroeira plants in five evaluation periods ${ }^{1}$.

\begin{tabular}{|c|c|c|c|c|c|}
\hline \multirow{3}{*}{ Irrigation solutions } & \multicolumn{5}{|c|}{ Plant height $(\mathrm{cm})$} \\
\hline & \multicolumn{5}{|c|}{ Day after planting } \\
\hline & 30 & 60 & 90 & 120 & 150 \\
\hline PSW & $13.92 \mathrm{~A}$ & $27.08 \mathrm{~A}$ & $36.15 \mathrm{~A}$ & $42.68 \mathrm{AB}$ & $44.23 \mathrm{~B}$ \\
\hline $25 \% \mathrm{DSE}+75 \% \mathrm{PSW}$ & $16.60 \mathrm{~A}$ & $31.45 \mathrm{~A}$ & $37.55 \mathrm{~A}$ & $38.33 \mathrm{~B}$ & $38.38 \mathrm{~B}$ \\
\hline $50 \% \mathrm{DSE}+50 \% \mathrm{PSW}$ & $11.53 \mathrm{~A}$ & $33.30 \mathrm{~A}$ & $37.43 \mathrm{~A}$ & $39.60 \mathrm{AB}$ & $35.48 \mathrm{~B}$ \\
\hline $75 \% \mathrm{DSE}+25 \% \mathrm{PSW}$ & $19.30 \mathrm{~A}$ & $28.05 \mathrm{~A}$ & $30.88 \mathrm{~A}$ & $40.40 \mathrm{AB}$ & $40.93 \mathrm{~B}$ \\
\hline $100 \% \mathrm{DSE}$ & $18.60 \mathrm{~A}$ & $34.00 \mathrm{~A}$ & $44.55 \mathrm{~A}$ & $53.00 \mathrm{~A}$ & $59.70 \mathrm{~A}$ \\
\hline \multirow{3}{*}{ Irrigation solutions } & \multicolumn{5}{|c|}{ Collar diameter $(\mathrm{mm})$} \\
\hline & \multicolumn{5}{|c|}{ Day After of Planting } \\
\hline & 30 & 60 & 90 & 120 & 150 \\
\hline PSW & $1.51 \mathrm{~B}$ & $2.70 \mathrm{~B}$ & $3.75 \mathrm{~B}$ & $5.03 \mathrm{~B}$ & $4.75 \mathrm{~B}$ \\
\hline $25 \% \mathrm{DSE}+75 \% \mathrm{PSW}$ & $1.66 \mathrm{~B}$ & $3.08 \mathrm{~B}$ & $3.63 \mathrm{~B}$ & $4.60 \mathrm{~B}$ & $4.25 \mathrm{~B}$ \\
\hline $50 \% \mathrm{DSE}+50 \% \mathrm{PSW}$ & $1.63 \mathrm{~B}$ & $3.05 \mathrm{~B}$ & $3.58 \mathrm{~B}$ & $4.20 \mathrm{~B}$ & $4.00 \mathrm{~B}$ \\
\hline $75 \% \mathrm{DSE}+25 \% \mathrm{PSW}$ & $2.03 \mathrm{~B}$ & $3.03 \mathrm{~B}$ & $3.75 \mathrm{~B}$ & $4.23 \mathrm{~B}$ & $4.75 \mathrm{~B}$ \\
\hline $100 \% \mathrm{DSE}$ & $3.03 \mathrm{~A}$ & $4.30 \mathrm{~A}$ & $5.88 \mathrm{~A}$ & $6.13 \mathrm{~A}$ & $7.05 \mathrm{~A}$ \\
\hline \multirow{3}{*}{ Irrigation solutions } & \multicolumn{5}{|c|}{ Total dry matter $(\mathrm{g})$} \\
\hline & \multicolumn{5}{|c|}{ Day After of Planting } \\
\hline & 30 & 60 & 90 & 120 & 150 \\
\hline PSW & $0.58 \mathrm{~A}$ & $3.90 \mathrm{~B}$ & $7.83 \mathrm{~B}$ & $6.85 \mathrm{~B}$ & $10.54 \mathrm{~B}$ \\
\hline $25 \% \mathrm{DSE}+75 \% \mathrm{PSW}$ & $0.96 \mathrm{~A}$ & $4.00 \mathrm{~B}$ & $7.65 \mathrm{BC}$ & $8.14 \mathrm{~B}$ & $7.09 \mathrm{~B}$ \\
\hline $50 \% \mathrm{DSE}+50 \% \mathrm{PSW}$ & $0.95 \mathrm{~A}$ & $3.28 \mathrm{~B}$ & $5.82 \mathrm{BC}$ & $5.85 \mathrm{~B}$ & $6.77 \mathrm{~B}$ \\
\hline $75 \% \mathrm{DSE}+25 \% \mathrm{PSW}$ & $1.19 \mathrm{~A}$ & $3.42 \mathrm{~B}$ & $3.83 \mathrm{C}$ & $6.92 \mathrm{~B}$ & $8.09 \mathrm{~B}$ \\
\hline $100 \% \mathrm{DSE}$ & $3.24 \mathrm{~A}$ & $9.39 \mathrm{~A}$ & $13.78 \mathrm{~A}$ & $19.82 \mathrm{~A}$ & $24.45 \mathrm{~A}$ \\
\hline
\end{tabular}

${ }^{1}$ Means followed by the same capital letter in line or lowercase in the column do not differ between each other at $5 \%$ probability by the Tukey test. $\mathrm{S}_{1}=75 \%$ soil $+25 \%$ bovine manure $\mathrm{S}_{2}=75 \%$ soil $+25 \%$ coconut fiber.

The fact that aroeira showed no difference in plant height until 90 days can be explained by the characteristic of the species, because it is a climax plant of the Caatinga vegetation and thereby has slow initial growth. Another factor that contributed to these results was the increment of macronutrients in the treatments with higher proportions of sewage effluent (Table 2).

Araújo et al. (2007) studied forest species of the Caatinga and concluded that Jucá seedlings irrigated with domestic sewage showed inferior initial growth compared with those irrigated with public-supply water and, from 40 days of age on, exhibited increasing development. Simões et al. (2013) found that the increase in sewage effluent doses led to higher growth of castor bean seedlings evaluated 42 days after emergence. Nóbrega et al.
(2007) studied the growth of Brazilian peppertree (Schinus terebynthifolius L.) and obtained a quadratic response with the applied dose of biosolid, while the highest value of plant height was caused by the dose of $35 \%$ (mean height of $16 \mathrm{~cm}$ ). In addition, at the end of the experiment, the seedlings showed heights superior to those recommended for planting $(>40 \mathrm{~cm})$, due to the growth evidenced in the last evaluations.

For collar diameter, the $100 \%$ DSE irrigation solution, in all evaluation periods, was superior to the others (Table 5). Collar diameter is a morphological parameter of seedling quality because the stem supports the plant, connecting the leaves and reproductive organs with the roots, allowing the exchange of assimilates between shoots and roots. Therefore, the thicker the stem, the greater the 
dilation in its vessels, promoting a more efficient transport of assimilates, guaranteeing greater support to the shoots and lower susceptibility to lodging.

Regarding total dry matter, there was also no difference between the solutions in the first 30 days after planting. However, at 60, 120 and 150 DAP, the $100 \%$ DSE solution led to superior mean values of total dry matter compared with the others, which did not differ. At 90 days, the 100\% DSE solution also promoted superior means and the solution of $75 \%$ DSE $+25 \%$ PSW caused the lowest means (Table 5). Biomass accumulation is an important characteristic related to plant growth; the higher its value, the better the seedling quality (DANTAS; ALMEIDA, 2008).

Rebouças et al. (2010) found similar results, studying cowpea irrigated with waste water from treated domestic sewage. These authors observed positive effect on total phytomass; plants irrigated with only domestic effluents increased total dry matter production by $117.07 \%$, evidencing that the amount of nitrogen in the waste water sufficiently met plant requirements in the absence of mineral fertilization in the soil, increasing dry phytomass production and other variables.

Greater growth and development of aroeira seedlings obtained through irrigation with domestic sewage effluent, in comparison to irrigation with public-supply water and the all dilutions, have been observed by many authors, who report that the presence of nutrients in the domestic sewage effluent (Table 2) stimulated the vegetative growth of the seedlings, due to the enhancement in soil fertility, especially through the incorporation of organic matter (ANDRADE FILHO et al., 2013). These benefits may also have reduced the deleterious effects of the effluent on the soil and plants, due to the high EC $\left(1.2 \mathrm{dS} \mathrm{m}^{-1}\right)$, and the toxicity by chloride and sodium ions present in the effluent.

\section{CONCLUSIONS}

The irrigation solution composed by raw sewage effluent or mixed with tap water increased the growth and improved morphological index of aroeira seedlings, being the better development found when plant of aroeira were grown in bovine manure + soil substrate under irrigation with solution containing $100 \%$ domestic sewage effluent.

\section{REFERENCES}

ANDRADE FILHO, J. et al. Atributos químicos de solo fertirrigado com água residuária no semiárido brasileiro. Irriga, Botucatu, v. 18, n. 4, p. 661-674, 2013.
ARAÚJO, B. A. et al. Uso de esgoto doméstico tratado na produção de mudas de espécies florestais da caatinga. Principia, João Pessoa, v. 2, n. 15, p. 48 $-53,2007$.

ASGHARIPOUR, M. R.; AZIZMOGHADDAM, H. $R$. Effects of raw and diluted municipal sewage efluente with micronutrient foliar sprays on the growth and nutrient concentration of foxtail millet in southeast Iran. Saudi Journal of Biological Sciences, Amsterdã, v. 19, n. 4, p. 441-449, 2012.

AUGUSTO, D. C. C. et al. Utilização de esgotos domésticos tratados através de um sistema biológico na produção de mudas de Croton floribundus Spreng. (capixingui) e Copaifera langsdorffii Desf. (copaíba). Revista Árvore, Viçosa, v. 27, n. 3, p. 335-342, 2003.

CARLINI, E. A. et al. Antiulcer effect of the pepper trees Schinus terebinthifolius Raddi (aroeira-dapraia) and Myracrodruon urundeuva Allemão, Anacardiaceae (aroeira-do-sertão). Revista Brasileira de Farmacognosia, Curitiba, v. 20, n. 2, p. 140-146, 2010.

DANTAS, V.; ALMEIDA, C. C. Efeitos da luminosidade no crescimento de mudas de Caesalpinia férrea Mart. ex Tul. (Leguminosae, Caesalpinoideae). Revista Acta Amazônica, Manaus, v. 38, n. 1, p. 5-10, 2008.

FERREIRA, D. F. Sisvar: a computer statistical analysis system. Ciência e agrotecnologia, Lavras, v. 35, n. 6, p. 1039-1042, 2011.

GOMES, J. M.; PAIVA, H. N. Viveiros florestais (propagação sexuada). 1. ed. Viçosa: Editora UFV, 2006. 116 p. (Caderno didático, 72).

GOMES, J. M. et al. Parâmetros morfológicos na avaliação da qualidade de mudas de Eucalyptus grandis. Revista Árvore, Viçosa, v. 26, n. 6, p. 655 664, 2002

HOPPE, J. M.; BRUN, E. J. Produção de sementes e mudas florestais. 2. ed. Santa Maria: UFSM, 2004. 388 p. (Caderno didático, 1).

LOPES, J. L. W. et al. Nutrição mineral de mudas de eucalipto produzidas sob diferentes lâminas de irrigação e substratos. Revista Brasileira de Ciência do Solo, Santa Maria, v. 31, n. 4, p. 713-722, 2007.

NÓBREGA, R. S. A. et al. Utilização de biossólido no crescimento inicial de mudas de aroeira (Schinus terebynthifolius Raddi). Revista Árvore, Viçosa, v. 31, n. 2, p. 239-246, 2007. 
OLIVEIRA, J. F. et al. Avaliação de mudas de sabiá e mororó fertirrigadas com esgoto doméstico tratado. Revista Agropecuária científica no semiárido, Pombal, v. 9, n. 4, p. 46-52, 2012.

REBOUÇAS, J. R. L. et al. Crescimento do feijãocaupi irrigado com água residuária de esgoto doméstico tratado. Revista Caatinga, Mossoró, v. 23, n. 1, p. 97-102, 2010.

SANTOS, J. D. et al. Plantas nativas do bioma caatinga produzidas com esgoto doméstico tratado. Revista Científica da UFPA, Curitiba, v. 6, n. 1, p. 1-8, 2007.

SARAIVA, V. M.; KONIG, A. Productivity PurpleElephant-Grass Irrigated With Treated Domestic Sewage in the Semiarid Potiguar and its Uses. Holos, Natal, v. 29, n. 1, p. 28-46, 2013.

SIMÕES, K. D. S. et al. Água residuária de esgoto doméstico tratado na atividade microbiana do solo e crescimento da mamoneira. Revista Brasileira de Engenharia Agrícola e Ambiental, Campina Grande, v. 17, n. 5, p. 518-523, 2013.

SOUZA, N. C. et al. Produtividade da mamona irrigada com esgoto doméstico tratado. Revista Brasileira de Engenharia Agrícola e Ambiental, Campina Grande, v. 14, n. 5, p. 478-484, 2010.

TEDESCO, M. J. et al. Análise de solo, plantas e outros materiais. 2. ed. Porto Alegre: Universidade Federal do Rio Grande do Sul, 1995. 174 p. (Boletim técnico, 5). 